$\xi=-1$

\title{
Happiness perspective of migrant labor households in the northeast, Thailand
}

\author{
Dusadee Ayuwat ${ }^{1 *}$, Wanichcha Narongchai ${ }^{1}$, Adirek Rengmanawong ${ }^{2}$, Nattawat Auraiampai ${ }^{1}$ \\ ${ }^{1}$ Department of Sociology and Anthropology, Labour and International Migration Service Center, \\ Faculty of Humanities and Social Sciences, Khon Kaen University, \\ ${ }^{2}$ Professional Level, Public Health Technical Office, Khon Kaen 40002, Thailand \\ *Corresponding author E-mail:dusayu@kku.ac.th
}

\begin{abstract}
This research focused on happiness perspectives of the migrant labour households in the Northeast, Thailand. The study relied on the qualitative methodology. The in-depth interview was conducted with key informants: village headman, senior persons, local officers and twelve heads of the international migrant households who had variation of migration patterns, selected by snowball techniques in one village within the O-lo District, Chaiyaphum Province. Data collection was done during April to May, 2017. The results were descriptive content analysis technique. The results indicated that most of the migrant labour households were farmers, grew rice and sugarcane and produced handicraft. Male labourers were the main group of the international migrants. The migrant labour households had only one labourer working abroad, with 2-month to10-year period of migration. The migration method that the labourers used in many destinations were through companies, brokers, the Department of Employment, or themselves. The migrant labour households defined happiness as good relationship within households, financial security, ability to manage debt and tension, household members being in good health, good relationship with others households, and safe and convenient life. The method of finding jobs abroad was related to working security of migrant labourers and happiness of the migrant labour households.
\end{abstract}

Keywords: Happiness, Migrant Labour Households, Migrant Labourer, Method of Working Abroad

\section{Introduction}

The national development under the First National Social and Economic Development Plan to the 12th (2017-2021) has brought changes in all levels of society. The outcomes of the first developmental period created tremendous growth in the economy and industry in the country, especially in urban areas where material growth was obvious. While urban areas have continuously been developed, the agricultural sector failed owing to the everdecreasing number of farmers [1]. This has led to the migration of rural citizens from rural areas to urban areas. Migration patterns are increasingly complex, for example, from rural areas to cities, from cities to rural areas, from cities to cities, and cross-national migration [2]. Migrating from rural areas have been changed towards migration to work abroad, where the number of migrants continuously increases. This can be seen from the number of applications to work abroad that amounted to 132,442 persons in 2013 , divided into 102,605 males $(77.47 \%$ ) and 29,837 females $(22.53 \%)$ [3]. Overseas migration has brought as high as an average of 66,161.1 million Baht of revenue into the country [1]. Migration is a livelihood strategy of the northeasterners [4]. Their families, however, have received both positive and negative impacts from oversea migration of these labourers. The impacts result from their working behaviors and ways of living in their destination place [5]. If a migrant labourer does not adjust himself properly, the chance of success will be less, and affect the family at places of origin. Normally, overseas migration means a circumstance that the labourer leaves the family for 3 to 5 years-working, depending on the job contract, in order to achieve his/her goals of household livelihoods. Meanwhile, the family has to take the burden from one missing member. Therefore, adjustment on occupation management, adjustments on psychological, social and household living conditions are required, which are associated with the happiness of the family back home.

This research is therefore interested to explore the happiness perspectives of the Northeast households of overseas migrant labourers. The results would illustrate the perspectives of labour households that are presented based on the differences of migration patterns. Thus, The recommendations of the study would be suggested as a guideline of happiness creation among the migrant labour households in the Northeast.

\section{Materials and methods}

The word "happiness" has been given a number of definitions by many organizations. For instance, Department of Mental Health defines the happiness as the happy living condition, which causes from ability of problem management regarding the livings and from the potential of self-improving for good quality of life. This covers goodness and morality under the changing social and environmental situations. In addition, Office of Health Organization [6] established indicators of the happiness including (1) Happy body, (2) Happy heart, (3) Happy relax, (4) Happy brain, (5) Happy soul, (6) Happy money, (7) Happy family, and (8) Happy society.

A number of research studies have explored the correlation of migration with happiness in the family. The research by De Jong, Chamratrithirong, and Tran [7] for example, showed that at the 
destination place where there are a great number of migrants, the migrant labourers are happier than at the place where there are fewer migrants. Some research found that happiness of migrants depend on the wages and incentives arising from migration. Another study found that migration of a son or daughter affects the health of mother or father at the home country [8]. Besides, some studies revealed that migration affect the household at places of origin, especially the skipped-generation family, in which the elderly have to look after the grandchildren [9]. All of the above are related to happiness of the family. It can be seen that the family context and migration patterns are associated with the happiness of the individuals, and related to migration process. It is believed in this research that happiness perspectives of Thailand's northeastern overseas migrant households are associated with the contexts of household, community, and the migration patterns of the labourers who are the family members (Figure 1).

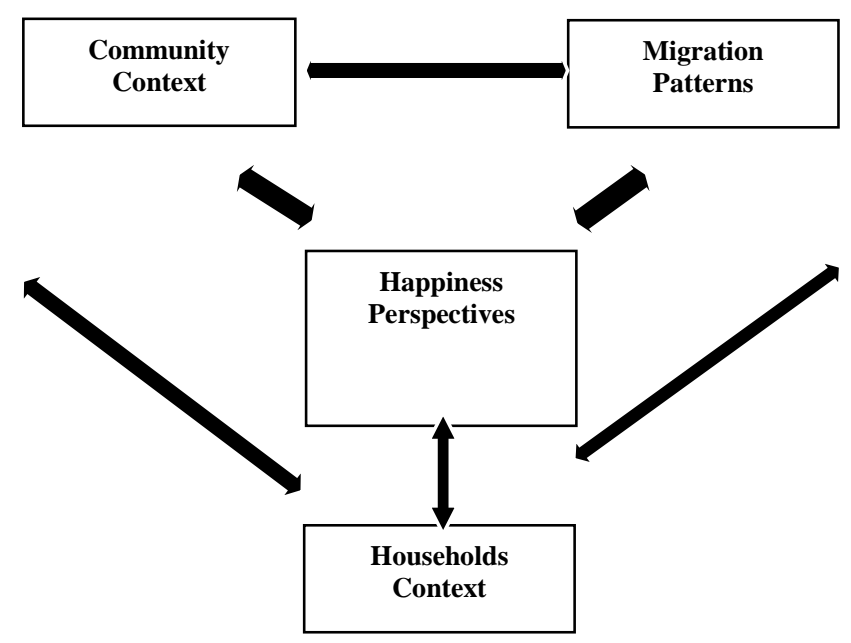

Fig. 1: Research Conceptual Framework

The qualitative methodology was applied in this research based on the phenomenology [10] for explaining happiness perspectives of the overseas migrant households. The unit of analysis was at the community and household levels. The research site was the O-lo Community, Phu Khiaw District, Chaiyaphum Province - where presented in the top list of the region where labourers migrated to work abroad and the area where migration took various patterns.

Key informants were divided into 2 groups: 1) a community senior, village headman, officers from Sub-district health promotion hospital, totaling 4 people; and 2) 12 migrant labour households where labourers had various methods of overseas working: 3 legal methods (through companies/brokers, through Department of Employment, and by employers); and an illegal method by entering the country as a tourist. Destination countries varied, including both Asia (South Korea, Taiwan, Singapore, and Israel) and Europe (Sweden, Germany). The households were also of various backgrounds. The father, mother, or wife of the migrant labourer was the informant of each household.

In-depth Interview [11] was conducted to collect data according to the designed approach to obtain in-depth and clear information, and non-participatory observation was also performed. The data collection was carried out from April to May, 2017. The data obtained was triangulated during the collection period. The descriptive analysis [11] was performed in order to clearly visualize the happiness perspectives of the households of labourers migrating abroad.

\section{Results}

\subsection{Community context}

The O-lo community is situated in Phu Khiaw District, Chaiyaphum Province. The community is $6.9 \mathrm{~km}$ away from the district and $79 \mathrm{~km}$ from the province, so it is easy to reach the district and province because of convenient transportation. The community considered as a large-scale community where comprises of 3 villages with totally 917 households, according to the division of governing areas for the state's administration of resources, as the number of extended families greatly increased. This community has been established for approximately 200 years, and presented as an ancient Thai-Laos community where was based on kinship society. However, the changing lifestyles have decreased practices of important traditions. The living of people in the community has clearly changed when the country has advanced into the capitalism-based production system. In addition, the conveniences from transportation and communication have enabled people to have a chance to continue their education in the district and province, and a chance to work away from home also.

In the past, villagers in the O-lo community were farmers, growing only glutinous rice and vegetables on the edges of paddy fields, and cotton for weaving cloth. In 1957, they began to grow kenaf. This became the shift of community economy. Rice was then grown for household consumption whereas other production was clearly for sale. In 1967, they began to hire labour to grow kenaf. Then in 1987, a big-size sugar factory was founded in the district; making most community allocated a part of their paddy to grow sugar cane, and sold it to the factory. One villager said, "....Rice paddy is for family meals, but sugar cane brings money to us..." At present, sugar cane plantation areas are increasing. In 2005, some households modified their land to grow rubber due to higher price of rubber in global market, and the land was suitable to grow rubber. At this stage, the community also started raising the good breed cattle for selling the cattle semen until a cluster was founded to invest on cow breeds )Figure 2(.

Presently, although the O-lo community situated in a rural area, the community has nearly all state-owned infrastructures for the people. There are Community Health Promotion Hospital, Community Primary Health Care where the village health volunteer (VHV) stays, and private clinic in the district area. Serious illness/injury cases can be sent to the district hospital shortly. Electricity reaches all households, and there are public landline telephone booths in many places. Most households have mobile phones to contact members who are working outside.

It can be seen that the community households have experienced in capitalism-oriented production or producing for selling. This system is subject to prices of goods in the market. If the investment is high, some households become indebted from this system. Therefore, a number of households produce non-farm goods by being the sub-contractors to produce items like curtains, wool hats. The non-farm jobs also include getting employment in other locality for extra earning to the family. Producing for selling results in the monetary value is getting more important. Lifestyle of each household is in a rush, while relationship among relatives is decreasing. This finding has also found in some research, which indicates that the capitalism and high competitiveness reduce interactions among family members $[12,13]$.

\subsection{Development of community migration}

In 1972, the country's development budget allocated to the road construction so that the community was more conveniently connected to the outside. Therefore, when the farm season ended, households usually sent their members to employ in any kind of jobs such as factory labour, labour in big cities where industries existed such as in Bangkok and the greater Bangkok. The study showed the dynamics of the overseas working, which could be classified into 4 periods based on the popular destination countries (Figure 3), namely:

The $1^{\text {st }}$ Period - The Middle-East Countries: In 1982, the villagers began to migrate to work in the countries in the Middle-East region, namely Saudi Arabia, Kuwait, Libya, because of good earnings. Most of the jobs related to construction works such as constructing oil refineries. In this period, only male migrants were able to work in these countries since these destination countries 
are the Muslim countries where female labourers were not permitted to work. The living conditions of the labourers were characterized by working in extreme heat and few entertainments because the Muslim laws strictly prohibited alcoholic drinking. Thus, remittances from the labourers was high.

The $2^{\text {nd }}$ Period - Taiwan: When popularity of employment in the Middle-East decreased, labourers then were seeking jobs overseas by changing working destination to Taiwan in 1988, where a lot of construction workers were required. The migrant labourers could be divided into 2 groups: 1 ) the former migrant labourers who used to work in the Middle-East and 2) the new generation group Now, female labourers were able to travel to work in Taiwan. They applied through an employment company in which they had to pay over 2940 USD for the working expenses. The jobs included construction of a factory or a railroad, where the salaries were 440-880 USD. At present, wages or salaries in Taiwan decrease tremendously, to 235-295 USD/ month. The households with a migrant member working in Taiwan believed that working and living in Taiwan were more flexible than in the Middle-East. The labourers were able to hang out and thus some labourers spent their money extravagantly. This finding was consistent with the work of Ayuwat, Im-emtham, \& Teerawisit [5].

The $3^{\text {rd }}$ Period - Singapore and Israel: Migration to Singapore began around 1990 . Works in Singapore generally required the skilled-labourers, so they were required to qualify the working skill tests which were conducted by the employer's company in Thailand. Employers preferred male labourers than females. A number of migrant labourers from the community preferred to work in Singapore because it was close to Thailand. Therefore, they would be able to visit their home during major festivals easily. Besides, the wages were good since the work required technical skills, i.e., around 1,176 USD/ month.

\section{Grow gluti- nous rice, vegetables, cotton )sub- sistent farmer(}

$\begin{array}{ccc}\text { Began } & \begin{array}{c}\text { Hire labour } \\ \text { to grow } \\ \text { growing } \\ \text { kenaf }\end{array} & \begin{array}{c}\text { kenaf } \\ \text { to improve } \\ \text { communi- } \\ \text { ca-tion }\end{array}\end{array}$

During the same period, some migrants from the community chose Israel as their working destination. The applications of working in Israel were managed by a broker or an employment company with high overseas working expenses, approximately 5,880 to 8,825 sector, for example, growing vegetables, fruits, flowers. People in the community believed that jobs in Israel gave good wages, but working condition was hard and continuous until they hardly had any rest. In addition, there was a risk of danger from war in the region (the cases were close to the dispute area). On the contrary, some households thought that the jobs were stable owing to a long contract period of 5 years. In 2014, Thai Government signed an agreement with the government of Israel to transfer labour from roughly 2,062 USD only [14]. Nevertheless, the interest of community labourers towards work in Israel did not increase, since they perceived the jobs in Israel were hard, troublesome, and the weather and surroundings were not inviting.

The $4^{\text {th }}$ Period - South Korea: South Korea has been a popular destination among male and female youths since 1992. The labourers migrating to South Korea from this community comprised of those who applied for the jobs legally and illegally. The legal application was conducted through the Division of Employment. In this case, the labourers had to take the Korean language test, it appeared that many of the villagers failed. Therefore, some chose to go there by smuggling, first in the form of tourists. Many labourers from this community were arrested and sent back to Thailand. The jobs of the migrant labourers there included construction works, work in factories and agricultural work in rural areas. The wages were around 1,176-1,470 USD. USD. The jobs at Israel included employments in the agricultural state to state. This reduced the migration management costs to

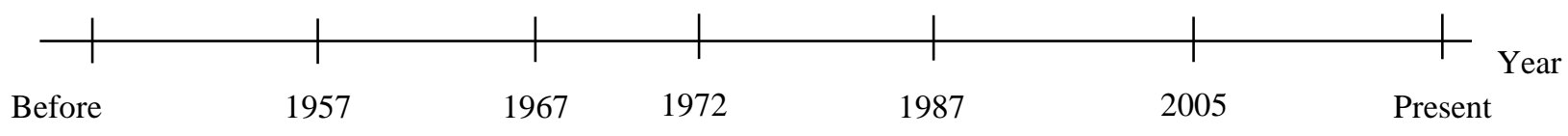

Fig. 2: Timeline of Career in Community

\begin{abstract}
Migrant labourers
began to migrate

to countries in the Middle-East.
\end{abstract}

1982

\author{
Migrant labourers \\ began to migrate to \\ Taiwan.
}

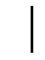

1988
Migrant labourers began to migrate to Singapore and Israel.<smiles>C=C</smiles>

1990
Invest in farming more; production for selling; employed in all jobs

Grow rubber
Big sugar mill
founded in the district. Began cane

\section{Migrant labourers began to migrate to South Korea.}

Fig. 3: Stages of Migration in the Community

Migration of the youths to work abroad is mostly decided by the youths themselves, not by decision of the families as in the past. Migration to work abroad enables the household of migrant labourers to receive the remittances. Many households used that money for rebuilding their houses, buying a car or other household utilities. Some has bought more subsistent lands. It is noted that some youths did not expect to work and send money back home.
This group migrated in order to open their visions and gain experiences rather than to make income for the family. These youths believe that living with their parents until the rest of life is the symbol reflecting weakness. This finding agreed with previous studies that demonstrated the will of youths in new-generation families who want to work away from home to build occupational stability and social acceptance $[13,14,15]$. 


\subsection{Characteristics of overseas migrant labourers' households}

The majority of the 12 households with the overseas migrant labourers in the rural northeastern area were the skipped-generation families in which the elderly lived with children who were born from the migrant labourers as well as the extended families. This is consistent with the work by Narongchai \& Ayuwat [9]. The number of members per family was one person to 8 persons, while the majority was 3-4 persons. The main occupation was farming growing rice, sugar cane, and rubber. In some households, the members were the freelance workers or labourers and officials. Hiring labour was the supplementary occupation held by 4 households. The incomes ranged from 1,470 USD, which was higher than the poverty line of 882 USD, to 8,825 USD per year (not including the remittance from migrant labourers). All households were found having debt from loan money, which was for sending the labourers to work overseas, and the debt for occupation investment at an amount of 882-5,880 USD. These debts were both formal and informal. However, the majority of the households had the savings from 29-882 USD, which was from the remittance from the migrant labourers.

\subsection{Characteristics of migrant labourers, methods of working abroad, and relationship between migrant la-} bourers and their households

Most of the households had only one member who migrated to work abroad. There was only one household where 3 members migrated at the data collection period. The other two members used the network from the first member to migrate. Most of the migrant labourers were male who aged from 25 to 49 years old, or an average of 35.5 years old. This is considered the able-bodied age range. Most of the labourers were the children of the family heads, and there were 4 households where the migrant labourers were the household heads themselves. The period of migration was from 2 to 10 years.

The expenses incurred from applying and travelling to the destination countries differed according to the methods used, i.e., from $882-2,440$ USD, or an average of 1,550 USD per case. Migration methods used could be divided into 3 methods: (1) By means of a company/ broker (5 households) to work as labourers in industrial factories in Taiwan and South Korea; (2) Through Department of Employment (3 households) to work in agricultural-related occupation in Israel and South Korea; (3) By the employer (1 household) to Madagascar to work as a foreman. Illegal migration taking the form of tourists was found in 2 households to work as labourers in an industrial factory and livestock business in South Korea. Most earned 882-2,058 USD per month, and were able to remit an amount of 295-885 USD per month to their households In addition, only one case sent the remittance back in every 2-3 months at an amount of 440 USD each time because the labourer worked illegally and the job was unstable. There was a case who had just been employed, and was not able to send any money to household at places of origin.

The relationship between the migrant labourers and their household - Most of the cases had good relationship and contacts were made every day to 2-3 days per time. Only 2 households contacted the labourers once every 2-3 months. The main contact channel was through social network application such as LINE, FACEBOOK, etc. which included both text messages and free calls or video calls where they could see each other. The topics of conversation were about the living condition in the destination countries, accommodation, food, health, and additional needs. Additionally, it was found that some households advised the labourers on how to manage and spend money so that the migrant labourers could save and become secure in the foreign country. Another topic was how to manage stress that most labourers found from working condition which was hard, and from language limitations in communicating with employers. However, some labourers were taken good care of by their employers owing to their hard working, patience and good intention to work.

Based on interviews with the households of illegal migrant labourers, the labourers contacted their families 1-2 times per month, especially at the time remittance was made. The main reason was both the labourers and the family worried that they would be arrested and deported. The labourers became suspicious of others and could not perform their work properly, which resulted in reduction of wages. As a result, there was no occupational and financial stability. Remittance therefore was irregular. Households having members working abroad illegally therefore had higher risks than those who sent their members to work legally.

\subsection{Happiness perspectives of the northeastern house- holds with migrant labourers working abroad}

Explanation of happiness perspectives of the households in the northeastern part of Thailand that had members migrating to work abroad was based on the happiness dimensions of the households and their happiness perspectives towards migration abroad of the members, with the following details:

\subsubsection{Happiness dimensions of the households with migrant labourers}

The households of migrant labourers defined happiness in 9 dimensions as follows:

1) Healthy - means the members in the households of migrating labourers are having healthy condition, with no congenital diseases or having congenital diseases that are not serious. The members are able to take care of themselves, are not addicted to alcoholic drinks, are able to consume good and useful foods, and exercise regularly. Some families add that happiness is ability to look after oneself in case of being ill, and to strictly follow on the doctor's advice.

2) Knowledgeable - means the members in the households of migrating labourers are eager to learn new things in order to improve themselves, such as attending training of various skills arranged by the community, seeking knowledge, continuing their education at higher level. The family should also support the members' need to improve themselves in order to be stable in their occupation. Some families define that improving of knowledge includes transfer of knowledge to others so that the knowledge is inherited. This shows that migrant labour households realized on the importance of knowledge transfer more than just acquiring skills.

3) Financial Security - means ability of migrant labourers' family members to manage their expenditure and income balance well. The members also know how to economize, save, and plan their own expenses. In case of debt presented, they are able to pay the installment punctually. The security covers the fact that the migrant labourers sent the remittances to the households regularly, and the remittances are used to invest for more earnings of the family. Some migrant labour households said happiness in this regard is high if the households could save the money every month. The remittent money can also be used for investment when the labourer returns home, resulting in financial security of the household. It can be seen that migrant labour households measure happiness from security of finance, i.e., having money to use, having savings that can be used for another occupation.

4) Social Responsibility - means generosity among family members, sharing responsibilities and being responsible for one's duties. This is because one missing member - who has migrated to work overseas - means the household burden has to be distributed among the remaining members. Social responsibility also refers to generosity at the community level. For example, the members show their care to others, sharing food and other consumer goods or farm produce to others, as well as helping others if they need labour force in their household activities. Some may do more than these such as giving advice to others in the community. 
5) Morality - means all members of the migrant labour households are seen behaving well and in line with religious practices. The members also make merit and donation, foster religion, pay respect to the god, be decent, not be involved bad deeds, and purify their heart. Young members of the family are taught and trained to distinguish between good and bad deeds, not to take advantages from the others, not to be selfish to other family members, others households, and to migrant labourers. The informant households believe that morality will protect their lives against indecent things and bring them luck.

6) Relaxation - means members of the migrant labour households know how to relax and manage their tension well through the creative activities such as cleaning the house, planting trees, watching movies, listening to music, talking with neighbors. Some households believe that if a member in the family is an introvert who does not talk to others, there will be pressure in the family, which may lessen happiness. The issue that leads to stress is related to migration of the member. This brings worries and fear, especially if migration is illegal.

7) Societal Dedication - means members of the migrant labour households have good relationships with their neighbors in the same community (mutual support), participate regularly in community's activities such as cleaning community places, joining annual merit makings. The members are able to ask neighbors for help in case of emergency such as taking a family member to hospital. The members feel secure in their lives and assets, even when the key person of the family has migrated to live abroad. The neighbors are willing to help taking care of the migrant labour family. Some households believe that if a member of the household becomes a community leader who is accepted by villagers in the community and follow the community's rules and regulations, the migrant labour households will be happier.

8) Warmth of Family - means members of the migrant labour households love each other and live peacefully together. This is reflected from giving moral support to one another. The members and migrating members can talk and consult in all topics, do activities together, have meals together, watch television together, or chat with the migrating member together via social media. Besides, the members do activities that bring warmth and security to everyone, and support all members to face the future or obstacles.

9) Household Facilities - means members of the migrant labour households possess all of the necessary utilities and equipment that facilitate all members with conveniences of life such as a car, a motorcycle, a washing machine, a vacuum cleaner, and air conditioners. The family has modern communication devices such as mobile phones with multiple applications to facilitate quick and easy contact with the migrating members abroad. This increases relationships between the migrating labourers and the family, making them happier. Some households see that conveniences in life with the utilities possessed cause from the remittance from the migrating members.

In conclusion, migrant labour households defined household happiness as good relationships, financial security, ability to manage debts, ability to overcome tension, members being in good health and having good relationships with their neighbors, feeling secure in terms of life and assets, and being convenient from utilities and facilities.

It can be seen that the 9 happiness perspectives given by migrant labour households are similar to the happiness dimensions of the Thai Health Organization in many respects, as shown in Table 1.

Table 1. Comparison of happiness perspectives of migrant labour households and happiness dimensions of Thai Health Organization

\begin{tabular}{cl|l}
\hline \multicolumn{2}{|c|}{$\begin{array}{l}\text { Happiness Perspective of } \\
\text { Migrant labour Households }\end{array}$} & Thai Health Organization \\
\hline 1. & Healthy & 1. Happy Body \\
$2 . \quad$ Knowledgeable & 2. Happy Brain \\
3. $\quad$ Financial Security & 3. Happy Money \\
4. $\quad$ Social Responsibility & 4. Happy Heart \\
\hline
\end{tabular}

\begin{tabular}{ll|l}
\hline 5. & Morality & 5. Happy Soul \\
6. & Relaxation & 6. Happy Relax \\
7. & Societal Dedication & 7. Happy Society \\
8. & Warmth of Family & 8. Happy Family \\
9. & Household Facilities & \\
\hline
\end{tabular}

\subsubsection{Happiness perspectives of migrant labour households and the methods of migration}

When the happiness perspectives of migrant labour households in the Northeast of Thailand were taken into consideration with the methods of their migration, it was found that the level of happiness assessed by the households and the happiness perspectives differed, and can be classified into 4 patterns as follows:

1) Legal migration via employer: There was one case of migrant labour household that was contacted directly by the employer, and was granted visa through the employer who came to take the labourer to the job in Madagascar. This household scored the happiness 8 out of 10 . The household did not think their happiness was full because the migrating member only returned home once a year, making the family worry and anxious. Nevertheless, the migrant labour households saw that happiness means the household earns money honestly and uses the money for consumers' goods, foods, and necessary utensils. They believe that happiness arises when there is sufficient money to spend. If there is no money, they will be unhappy and struggle. Money can buy any facilities especially the new mobile phone model, which enables the family members to contact the migrating labourer even though they are far apart. Money also enables members to eat good and useful foods that make them healthy.

2) Legal migration via Department of Labour: There were 3 households whose members migrated abroad via the Department of Labour. The migrating labourers were working in the farm in Israel and South Korea. They scored their happiness at 8-9 out of 10. They reported that the remaining members in the family scarcely talked to each other, showing lack of relationships. Moreover, the migrating labourers did not receive the wages at the right time. They believed that household happiness is the good relationship within the family and also with the migrating labourer. They are happy when the financial status is secure, and they know how to economize, plan the use of money, manage debts, and manage stress by many ways such as cleaning the house, meeting and talking with friends and people in the community. Their happiness also means the members are healthy, having good relationship with neighbors, securing in their lives and assets, and living conveniently with complete utilities and facilities.

3) Legal migration via an employment company/broker: There were 4 households in which the members migrated to work through an employment company or a broker. They worked as factory labourers in Taiwan and South Korea. They evaluated their happiness at 6-10 points. Some of these households were worrying about health condition and about their children. Some households were confident with the broker/company, and had no worries in this respect. This could be because the broker did everything for the labourers to travel to the destination country [4]. The household rating their happiness at 6 out of 10 explained that tension could reduce their happiness, especially about the health of the member. Some households explained that the stress was caused by the migrating labourer who decided to start relationship with someone met at the destination country. The family feared that their migrating member might be deceived. These households defined happiness as having financial security, savings, having good health of family members with no serious disease, members living together, having good relationships in the family and with people in the community, having chance to foster religion, being convenience in life from utilities, and more importantly, knowing how to manage stress, relaxing, and preparing for things that could happen. In fact, some households are still lack of management capacity in this regard. 
4) Illegal migration by the labourers themselves: There were 2 households that the members migrated illegally to the country of destination in order to work in an industrial factory and at a farm in South Korea. Their households evaluated the happiness at 5-6 only since they knew that they were not secure financially, and the migrating labourers were not secure either. The families at places of origin got effects because they were waiting for remittance, which was not regularly. The households were in tension for fear that the labourers would be caught and deported without receiving the wages. They thought about the happiness as financial security and ability to spend money without any shortage, ability to manage debt, good relationships within the family and with neighbors, ability to contact the migrating labourer regularly, household members being in good health, households having all facilities, being safe in terms of life and assets in the community, and having convenient transportation including transportation to buy things and to go to the health station.

It can be seen that the different methods of migration to work abroad resulted in different rates of happiness evaluation and different happiness perspectives. Legal migration methods and illegal method reflected clear differences. The households with members migrated to work illegally had stress and worries of the situation of the migrating labourers overseas and of the irregularity of wages and hence the remittance. The worries and stress were higher than in the households that sent their members to work abroad legally. This shows that the households saw that migration method of working abroad correlated to the stability of work of the migrating members and household happiness.

\section{Discussion}

The result of the research in happiness perspectives of households having migrant labourers abroad showed that the households' definitions of happiness correlated with the people who were left behind and the people moving away or the migrant labourers. The happiness dimensions were correlated to the behaviors of the people left behind, namely, decent behaviors and manners towards one another, responsibilities over household chores and community's activities, besides economizing because they relied on the remittance money from the migrating labourers, which differed from one labourer to another depending on the migration method at the first start. However, the happiness perspectives of the households included convenience obtained from being able to buy utilities using the remittent money. This made the dimensions of happiness of migrant labour households wider than the dimensions stipulated by Thai Health Organization [6].

Additionally, happiness of the migrant labour households depended on worries about the member living abroad, the migrating member's working condition and wages, the member's relation with an opposite sex and relationship with colleagues. These depended on the ability of the migrating labourers to adjust themselves with the new surroundings in the destination place. This finding is consistent with the research findings of Jones [16] who concluded that the conditions of migrant labourers affect the happiness of the households at the origin country.

Although it was found in this research that the migrant labour households were happy in many dimensions from self-evaluation, the levels of happiness evaluated were not high in the group of households from which a member migrated to work illegally. Therefore, some mechanism should be created for understanding of the legal migration method for the households and the labourers before they make decision to work abroad. This will reduce stress and worries of the households, bringing true happiness to them.

\section{Acknowledgements}

This article uses the information from the research project on "Happiness of Migrant labour Households in the Northeast, Thailand." The research scholarship was granted by Faculty of Humanities and Social Sciences, Khon Kaen University. The researchers extends their thanks to all migrant labour households under this study and officers of the Sub-District Health Promotion Hospital for their good cooperation in the data collection process.

\section{References}

[1] National Statistics Bureau. Executive Summary on Survey of Population Migration (2012), Retrieved June 14, 2017 from: http://service.nso.go.th/nso/nsopublish/ service/survey/ MigrantExec51.pdf.

[2] College of Demography, Chulalongkorn University. Migration (2011), (Online). Retrieved June 15, 2917 from: http://www.cps.chula.ac.th/research_division/basic_data/b_ migration.html.

[3] Office of Overseas Employment Administration, Department of Employment, Ministry of Labor (2013), First Quarter Situations of Cross-Regional Laborers 2013. Retrieved June 13 , 2016 from: http://wvvw.msociety.go.th/article attach/10412/15302.pdf.

[4] Ayuwat D \& Chamaratana T (2014), The role of labour broker networks in setting the price of working abroad for Thai migrant workers. Asia-Pacific Population Journal 28(2), 51-68.

[5] Ayuwat D, Im-emtham S \& Teerawisit A (2010), Lifestyles of Thai Labourers in Taiwan: A Study in the Destination Country. Humanities and Social Sciences Journal 27(1), 1-28.

[6] Thai Health Organization. Manual for 8 Happiness Items. Bangkok: Thai Health Organization (2007).

[7] De Jong G, Chamratrithirong A \& Quynth-Giang T (2002), For better, for worse: life satisfaction consequences of migration, International Migration Review 36(3), 838-63.

[8] Kuhn S, Randall, Bethany Everett \& Rachel Silvey (2011), The effects of children's migration on elderly kin's health: A counterfactual approach, Demography 48 (1), 183- 209.

[9] Narongchai W \& Ayuwat D (2011), Patterns of Co-resident of Skipped-generation in Isan Migrant Family. Proceeding of The 5th Annual International Conference on Sociology, Greece, 9. 12 May 2011, 60.

[10] Creswell JW (2004), Qualitative Inquiry and Research Design: Choosing Among Five Traditions. Thousand oaks, CA. Sage.

[11] Phothisita C (2004), Science and Arts of Qualitative Research. Bangkok: Amarin Printing and Publishing.

[12] Etwongsa P, Chuanwan S \& Churat W (2016), Final Report of Happiness of Thai Rural Household under Socio-Demographic Changes. Bangkok: Office of Thailand Research Fund.

[13] Chen F \& Korinek K (2010), Family Life Course Transitions and Rural Household Economy during China's Market Reform. Demography 47 (4), 963-987.

[14] Department of Community Development, Report on Debts and Financial Status in the Poverty Mitigation Project (2014), Rerieved June 16, 2017, from: http://203.114.112.233/CDDCENTER/cdd_report /oth_r01.php.

[15] Harrell S (2000), Review of the Changing Family in Comparative Perspective: Asia and the United States. Journal of Japanese Studies 26 (1), 160-164.

[16] Richard Jones C (2014), Migration and Family Happiness in Bolivia: Does Social Disintegration Negate Economic Wellbeing? International Migration 52(3), 177-193. 